\title{
The Emergence of the Distinction between Complete and Incomplete Causes from Avicenna to al-Abharī
}

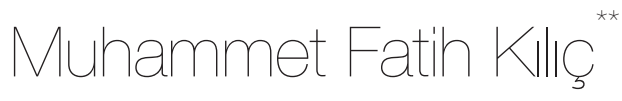

Translated by Abdullah Özkan***

\begin{abstract}
In this study, I explore the historical stages of the development of the distinction between complete and incomplete causes (al-illa al-tämma and al-illa al-nāqișa), which first emerged during the thirteenth century and was frequently in use thereafter in philosophical and theological writings. For this purpose, I trace the evolution of one such passage in Avicenna's (d. 428/1037) Ishärät, namely, III.V.8, in the context of causal sufficiency during post-classical Islamic thought. Abū al-Barakāt al-Baghdādī (d. 547/1152), Suhrawardì (d. 587/1191), and Fakhr al-Dīn al-Rāzì (d. 606/1210), all of whom provided the first examples of a concept of a complete cause, offer an important notion of this distinction. Moreover, we can read al-Rāzî̀s definition of a complete cause in his al-Mațālib, with regard to its function, as an attempt to include the divine will in the causal processes. However, none of those definitions present a clear distinction between these two types of causes that would enable one to provide a clear definition for a complete cause. The first examples of a clear distinction between these two causes are provided by Athīr al-Dīn al-Abharī (d. 663/1265) and Najm al-Dīn al-Kātibī (d. 675/1277). This distinction occupied an essential place in the chapters of causality included within philosophical and theological texts written after the thirteenth century.
\end{abstract}

Keywords: Causality, distinction between complete and incomplete causes, Avicenna, Abū al-Barakāt alBaghdādī, Suhrawardī, Fakhr al-Dīn al-Rāzī, Athīr al-Dīn al-Abharī.

\footnotetext{
* I previously presented most of the passages used in this article in I. Uluslararast Sosyal Bilimler Sempozyumu as a paper: "İslam Düşüncesinde Bir Kavramın Doğuşu: Tam İllet/Sebebin Kısa Tarihi." See, Asos Congress Bildiri Kitabı (Elazığ: Asos Yayınları, 2016), 1866-76.

** Assist. Prof., Mardin Artuklu University, Department of Philosophy..

Correspondence: mimfatih@gmail.com

*** Res. Assist., Çanakkale Onsekiz Mart University, Faculty of Theology.
} 


\section{Introduction}

W hile explaining Avicenna's (d. 428/1037) cosmology, Jon McGinnis states that "the effect must be necessitated simultaneously with the existence of the effect's complete cause" and "the Necessary Existent is assumed to be the complete cause of all things." This statement gives the impression that the concept of a complete cause is used in the context of the causal sufficiency possessed by the cause with regard to its generation of its own effect, which we find in Avicenna's texts. However, the complete cause and/or distinction between it and an incomplete cause (al-illa al-tämma and al-illa al-nāqișa) that arises in the context of causal sufficiency does not exist in Avicenna's texts.

However, Avicenna does provide some explanations about these causes in alShifä': Ilāhiyyāt, IV.III. Here, he is more interested in the conditions of thing's perfection than in a cause's sufficiency with regard to its effect's generation. Accordingly, the complete, the highest form of which is seen in God, is defined as a thing that exists in the most perfect form, whereas the incomplete describes the things that we observe in the sublunar world and thus are, by default, imperfect. ${ }^{2}$ In parallel with these explanations, Avicenna makes tamämiyya, which is derived from tämm, an adjective of the cause. When he uses al-illa al-tamämiyya, he assigns a meaning to it in relation to the final cause, which causes that thing to achieve perfection. ${ }^{3}$ As a matter of fact, Fakhr al-Dīn al-Rāzì (d. 606/1210), who is a careful reader of Avicenna, points out that philosophers understood complete cause in relation to the final cause by stating that they called the determining component in the process of causation ( $d \bar{a} \hat{\imath})$ "the final cause and sometimes the complete cause" (al-ḥukamā' yusammūnahū bi-al-îlla al-ghäiyya wa qad yusammūnahū ayḍdan bi-al-'illa al-tāmma). ${ }^{4} \mathrm{Al}$-Rāzì provides a similar explanation in his al-Mabāhith, where he states that philosophers use complete to mean "the sum of every perfection that a thing has in actuality" (jamī'u kamālät al-shay' häṣila lahü bi-al-fíl). In relation to this, when the complete existent is considered a cause, it becomes a principle that

1 Jon McGinnis, Avicenna (Oxford, NY: Oxford University Press, 2010), 199. For a similar usage of "complete cause" in the context of Avicenna, see Anthony Ruffus and Jon McGinnis, "Willful Understanding: Avicenna's Philosophy of Action and Theory of the Will”, Archiv für Geschichte der Philosophie 97/2 (2015): 161.

2 Ibn Sīnā, Kitāb al-Shifā', al-Ilāhiyyāt, ed. Ibrahīm Madkūr, al-Ab Qanawātī and Sa īd Zāyid (Cairo: alHay'a al-'Āmma li-Shu'ūn al-Mațābi‘ al-Amīriyya, 1960), I, 188, 5-10, 14-15; Ibn Sīnā, al-Ta'līqāt, ed. Husayn Majīd 'Ubaydī (Baghdad: Bayt al-Hikma, 2002), 291,16-292,5.

3 Ibn Sīnā, Kitāb al-Shifä', al-Ilāhiyyāt, II (VI.V), 296,4-5.

4 Fakhr al- Dīn al-Rāzī, al-Mațālib al-'āliyya min al-ílm al-ilāhī, ed. Aḥmad Hịijāzī al-Saqā (Beirut: Dār alKitāb al-'Arabī, 1987), III, 10,4-5. 
gives perfection to other things (mabda' li-kamālāt ghayrih), just as in the case of a final cause..$^{5}$ In this case, Avicenna contends that the complete existent, which is also perfect, also appears as the giver of perfection to other things when it is considered a cause. ${ }^{6}$

The fact that Avicenna, whose ability to invent new concepts is beyond question, attributes completeness and incompleteness to the cause signifies the perfection that it gives to its effect rather than its sufficiency. This raises the following question: In which thinkers' hands and in which debates did the distinction of complete and incomplete causes (hereinafter "distinction") seen in the philosophical-theological texts written in the thirteenth century and afterwards evolve, and did they take place in the context of the cause's sufficiency during causation? Modern studies on Islamic philosophy have provided no satisfactory answer. Therefore, this study seeks to describe the emergence of this distinction during the process of causation that was formulated long after Avicenna's death.

\section{The Distinctions Made in Classical Period}

Before this distinction appeared, there were three classifications of the causes' role during causation. Foremost among them was the sabab-illa distinction found in the theological tradition ( $\mathrm{kalām}$ ) of the classical and post-classical periods. According to the version presented by Avicenna's contemporary Qādī 'Abd al-Jabbār (d. $415 / 1025)$, even though the sabab is a necessary condition in terms of generating its effect, it does not necessarily necessitate the effect's generation. Within this framework, the sabab originates within the object and has the potential to change with regard to its activity during causation. On the other hand, the 'illa reserves the causal inclinations that the object has toward a specific direction by influencing it from the outside. For example, although man's possession of power corresponds to

5 Fakhr al-Dīn al-Rāzī, al-Mabāḥith al-mashriqiyya fì al-ílm al-ilāhiyyāt wa-al-țabīìyyāt (Qum: Intishārāt Bīdār, 1370), I, 450,8-12.

6 When Avicenna attributes completeness to the necessary existent, which is also the first cause (al-'illa $a l-\bar{u} l \bar{a})$ in his system, he means the final cause that gives perfection to existence. For example, see Ibn Sīnā, Kitāb al-Shifä', al-Ilāhiyyāt, II (VIII.VI), 355,6-10. These explanations, which Avicenna makes in the context of perfection, can be considered in conjunction with what Muslim philosophers inherited from the Ancient and Hellenistic worlds. In fact, the Greek terms teleios and ateles, which describe the conditions of perfection, were translated into Arabic as tām/kāmil and ghayr tām/nāqis. See Robert Wisnovsky, "Avicenna on Final Causality" (PhD dissertation, Princeton University, 1994), 11-12. This situation clarifies why Avicenna prefers the meaning of final causation, which occurs in the debates related to perfection, rather than the meaning of sufficiency that a cause(s) have with regard to its generation of its effect. This latter meaning is seen during the thriteenth century and afterward when he uses "complete" and "incomplete" in the context of causation. 
the sabab, which enables him to act in various directions, his preference to act in a specific direction corresponds to the 'illa. ${ }^{7}$

Avicenna, who uses sabab and 'illa as synonyms, makes no such distinction. However, his works contain two classifications that could be viewed as being related with the causes: (1) the distinction between internal and external causes inspired by the Neo-Platonist distinction of immanent and transcendent causes ${ }^{8}$ and (2) the distinction between essential and existential causes, which depends upon Avicenna's original distinction between essence and existence. Avicenna made the first distinction in his early and middle works, where he contended that the internal causes participate from within the effect as material and formal causes, whereas external causes generate the effect's existence from outside as the efficient and final causes. ${ }^{9}$ After the distinction between essence and existence became the determinant characteristic of his philosophy, Avicenna made a distinction between the essential and existential causes in al-Ishārāt $t^{10}$ and specified matter and form, which constitute the object's essence by participating in it and therefore not existing by themselves, as the essential causes and the agent and intention, which cause the emergence of something via external influence, as the existential causes. ${ }^{11}$

\section{Avicennian Roots}

If the intellectual roots of this distinction between complete and incomplete causes, which began to be made about two centuries after Avicenna's death in the context of casual sufficiency during causation, is sought in his works, one can find some clues in terms of its complete part. The most important clue can be found in

7 Qādī 'Abd al-Jabbār, al-Mughnī fĩ abwāb al-tawhìd wa-al-'adl, ed. Muhammad Muṣțafā Hilmī and Abū al-Wafā al-Ghunaymī (Cairo: al-Dār al-Mișriyya, 1963), IX, 48, 20-24. Also see Yunus Cengiz, Mu'tezilede Eylem Teorisi Kâdî Abdülcebbar Örneği (İstanbul: Düşün Yayıncılık, 2012), 99. In his work, where he discusses causality according to the mutakallimūn of the classical period, Osman Demir states that, especially after Qādī, there is a move toward a distinction in which 'illa becomes more influential and prominent in the process of causation thansabab. In addition, in this context Demir gives the definitions of 'illa and sabab made by Qādī's student al-Nīsābūrī (d. 400/1009) and Ibn Hazm (d. 445/1064). See Osman Demir, Kelâmda Nedensellik: İlk Dönem Kelamcılarında Tabiat ve İnsan (İstanbul: Klasik Yayınlar1, 2015), 26-28.

8 Robert Wisnovsky, “Towards a History of Avicenna's Distinction Between Immanent and Transcendent Causes", Before and After Avicenna: Proceedings of the First Conference of the Avicenna Study Group, ed. David C. Reisman (Leiden and Boston: Brill, 2003), 49.

9 See, for example, Ibn Sīnā, Kitāb al-Hidāya, ed. Muhạmmad 'Abduh (Cairo: Kulliyyāt Dār al-'Ulūm, Jāmi‘a Qāhira, 1974), 243,6-244,4.

10 Wisnovsky, “Towards a History of Avicenna's Distinction”, 67

11 Ibn Sīnā, al-Ishārāt wa-al-tanbīhāt, ed. Sulaymān Dunyā (Cairo: Dār al-Ma'ārif, 1960), III (IV.5), 13,3-7. 
an admonition of his al-Ishārāt, namely, III.V.8, which is "on the actual completion of a cause as a cause" and accompanies the explanation about the conditions of causation in the sublunar world:

The effect's existence depends upon the cause, for the cause is in a state (hāl) by virtue of which it is a cause, such as the state of nature, volition, or some further thing that must be one of the external things that take part in it. All of these ensure the completion of the cause as an actual cause (tatmim kawn al-illa 'illatan bi-al-fit). Such things are exemplified by the instrument, as in the carpenter's need for the hammer; the matter, as in the carpenter's need for wood; the assistant (mu'äwin), as in the sawyer's need for another sawyer; the time (waqt), as in a human being's need for summer; the motive

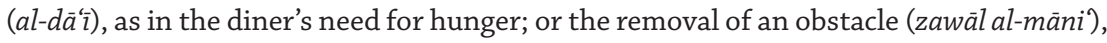
as in the washer's need for the removal of darkness. The effect's nonexistence depends upon the nonexistence of the cause in a state by virtue of which it is an actual cause, whether the cause itself exists, but not in that state ( $h \bar{a} l)$, or whether it does not exist at all. If there is no external impediment and if the agent itself exists, yet without being a cause by essence, then the effect's existence will depend upon the existence of the aforementioned state. Thus, if such a state exists, whether as a nature, as a decisive volition, or as something else, the effect's existence becomes necessary. ${ }^{12}$

Here, Avicenna elucidates on the conditions in which the cause emerges as a cause in actuality and thus necessitates the complete emergence of its effect. In other words, he explains how a cause becomes a "complete cause." Accordingly, when the cause's conditions that are necessary for causation come together and become complete, the cause becomes sufficient and complete with regard to generating its effect. Thus, the effect necessarily comes into existence from the cause. This explanation is not about the thing's perfection or the perfection that the cause gives to the thing, but rather about the sufficiency of the cause that becomes complete during causation with regard to its effect's generation. This fact shows that the explanation in question is about the first part of the distinction between complete and incomplete, that is to say the complete cause, which emerged after Avicenna. Nașīr al-Dīn al-Ṭūsī (d. 672/1274), who lived when this distinction was in circulation, provides some explanations about this admonition in his Sharh al-Ishārāt.

Avicenna [here] wants to admonish that the effects do not fail to appear after their complete causes. (yurīd an yunabbih 'alā anna al-ma'lūlāt lā tatakhallaf an 'illatihā al-tāmma). ${ }^{13}$ 
In other words, if there is a cause that deserves to be called "complete", then the effect comes into existence necessarily because the cause is sufficient to generate its effect. On the other hand, if there is an incomplete cause (i.e., an insufficiency with regard to the conditions' existence and the impediments' removal), then we cannot expect the effect to come into existence necessarily because the cause remains incomplete in actuality. The fact that al-Țüsi points to the complete cause here in his comments on this passage indicates the possibility that Avicenna was the inspiration for this distinction made in the context of causal sufficiency.

\section{The Contributions of Abī al-Barakāt}

One can come across al-Ṭusis's concept of a complete cause and, in connection with it, the notion of a cause whose effect does fail to appear after it, before the complete-incomplete cause distinction obtained its standard structure during the thirteenth century. In his Kitāb al-Mu'tabar, Abū al-Barakāt al-Baghdādī (d. 547/1152) utters the phrase "the cause whose causality is complete" (al-sabab al-tämm al-sababiyya / 'illa tämma al-illiyya) in the context of several different discussions. This phrase covers pretty much the whole notion of a complete cause, which would acquire its standard structure in the following century. We come across his first usage of this phrase in the logic section of his Kitäb al-Mu'tabar, where he states that the existence of the cause whose causality is complete (al-sabab al-tämm al-sababiyya) leads us to the existence of its effect, just as the knowledge of something leads us to the knowledge of the unknown. ${ }^{14}$ Thus, if the complete cause exists, then its effect will come into existence with it concurrently. In other words, since the complete cause meets the required conditions of causation and, in this respect, has full causal sufficiency, then it necessarily generates its effect.

Al-Baghdādī, who appears to use sabab and 'illa interchangeably, this time uses "illa tāmma al-illiyya" instead of "al-sabab al-tāmm al-sababiyya". Moreover, he crystallizes his notion of causation, which depends upon the epistemological connection between the cause and the effect, and establishes a relationship between them that necessitates each other both ontologically and epistemologically. The key term that makes this relationship possible is the cause whose causality is complete: 
If the second comes into existence from the first, then the existence of the second is the proof of the existence of the first. Thus, if this cause is completed with regard to its causation, then the existence of the first is the cause of the existence of the second and the proof of its existence. Every cause whose causality is complete (kull 'illa tämma al-illiyya) points to the existence of its effect. For this reason, the second comes into existence provided that the first exists, and from the knowledge of the second the first is known necessarily. ${ }^{15}$

In this passage, al-Baghdādī puts forward "the cause whose causality is complete" in connection with the problems of existence that have to be considered in the context of proving the necessary existent's existence. This passage, which can be interpreted within the framework of the Avicennian distinction between necessary and possible existence, elucidates that every possible existent that needs a cause clearly points to the existence of the cause whose causality is complete and to the existence of necessary existence. However, al-Baghdādì makes no direct connection here with III.V.8 in Avicenna's al-Ishārāt.

Al-Baghdādì's statements in al-Mu'tabar seem to have a more direct connection with the passage of al-Isharät in question that can be found in the tenth part of the section of divine science (al-ilm al-ilähì), which is devoted to cause and effect. First of all, in this part he states that the cause of nonexistence is the nonexistence of the cause and those circumstances that prevent it from taking any action (mu'äwiqa al-fil). With regard to the second case, he attributes the completion of a cause and its realization in order to generate its effect, or its becoming a "complete cause", to its ability to fulfill the necessary conditions and remove the obstructive elements (fa inna al-illla tatimm 'illiyyatuhā ma'a al-sharț al-mūjib fa muzìl al-sharț al-mūjib 'an al-ílla al-müjiba huwa muzìl al-ílla 'an 'illiyyatihāa). ${ }^{16}$ While al-Bahgdādī points to the elements that complete the cause (e.g., instrument, matter, and motive) with which Avicenna deals in detail via "the fulfillment of the necessary conditions", he includes in his explanations "the removal of the obstructive elements" as well.

Taking al-Baghdādi's connection with Avicenna into account, one can say that the latter's expression of "the completion of the cause as an actual cause" (fi tatmim kawn al-illa 'illa bi-al-fi'l) is transformed into al-Baghdādì's expression of "the cause whose causality is complete" (al-sabab al-tāmm al-sababiyya / 'illa tāmma al-illiyya). Furthermore, al-Baghdādī goes beyond Avicenna's causal explanations, which seemed to be connected (from his examples) with the physical processes in the sub- 
lunar world, and raises the discussion to the metaphysical level. This contribution is viewed as an important step toward the complete-incomplete cause distinction. Even though al-Baghdādì does not use "the complete cause," his own "the cause whose causality is complete" includes both the term's meaning and wording and opens the door to possible interpretations on how to understand the incomplete cause. One can infer from his usage of "complete cause" and non-usage of "incomplete cause" that the latter cause is unable to generate its effect because the necessary conditions for its complete causation remain unfulfilled.

\section{The First Attempts of Definition: Al-Rāzī and Suhrawardī}

Al-Ràzì provides one of the first examples of the meaning of the complete cause that al-Baghdādī employs in a sense as well as its next step in the form of "complete cause." In his comments on one remark of Avicenna (III.V.10) about the emergence of possible existence in his Sharh al-Ishārāt, he summarizes Avicenna's purpose by appealing also the term "complete cause" as such:

\footnotetext{
You should know that this part contains two purposes: The first of these, giving preference to one side over the other in the case of possibility, happens only with the existence of a preponderator (murajiih) and that Avicenna accepts this as a necessary proposition that does not require an apodeictic demonstration. The second is that in the case that the complete cause does exist, then the effect emerges necessarily (huṣūl al-ma' wäjib 'inda hușül al-ílla al-tāmma). That is an apodeictic demonstration. ${ }^{17}$
}

Al-Rāzī's conceptualization of the complete cause, which he makes here in the framework of Avicenna's philosophy, can be understood in conjunction with the metaphysical nature of the necessary connection between cause and effect when the passage's context is taken into consideration. According to this understanding, the complete cause can be considered the metaphysical cause that has enough causal sufficiency to necessitate its effect. In his al-Mabāhith, al-Rāzī draws attention to this necessary connection on the physical level when he discusses the confirmation of incidental causes (ithbāt al-asbāb al-ittifāqiyya). In that discussion, which seems to be taking place within the context of Avicenna's physics, al-Rāzì uses "complete cause" when explaining those causes considered to be outside the incidental causes that occur sometimes and rarely, rather than constantly and mostly: 
The cause generates its effect either by originating it from itself or by not originating it from itself. If it originates from itself, then it has to be independent with regard to its influence. In this way, the generation of the effect from the cause becomes constant [not sometimes or rarely], because the effect does not fail to appear after its complete cause in causation (anna al-ma'lūl yamtani' takhallafuhū 'an-al-'illa al-tāmma fi-al-'illiyya). ${ }^{18}$

In addition to the explanation of the above passage of Sharh al-Ishārāt that is made about the necessary connection between the complete cause and its effect, al-Rāzì states here that the complete cause does not need any other causes while generating its effect, and that its effect comes into existence from its cause not incidentally but constantly. Here, both usages of "complete cause" are discussed in the context of casual sufficiency, which indicates an understanding that the complete cause, with regard to its causation, is necessarily connected with its effect. However, these usages arise in both a physical and a metaphysical context pertaining to Avicenna's thoughts, rather than from any attempt to show how al-Rāzì thought about causation. Accordingly, from the context of his explanations, one cannot formulate the direct definition of "complete cause" from al-Rāzīs perspective, but only an evaluation related to that term's possible meanings in those usages.

Even though this short participle phrase enables al-Rāzì to carry his usage of "complete cause" forward in his al-Mațālib, ${ }^{19}$ he nevertheless accommodates an explanation about its essence. This usage and explanation occurs in the context of whether removing the effect means to remove the cause, which he situates and discusses in passage III.V.10 of Sharh al-Ishärāt under the main problem of the emergence of possible existence in connection with the existence of a preponderator (murajih). At the center of this sub-problem is the problem of the concurrency of cause and effect, namely, their simultaneity in time. Al-Rāzì, who says that Avicenna had first embraced the view that "the removal of the cause follows from the removal of the effect ${ }^{20 "}$ and then opposed it later on ${ }^{21}$ writes:

We see that the forms and the accidents [in the sub-lunar world] perish after their existence. Their ceasing to be and perishing [according to Avicenna] necessitate the removal of their causes. Thus, the removal of their causes necessitates their removal. In this case, the removal of the forms and the accidents indicates the removal of their causes, 
and the removal of these causes indicates the removal of their causes. In this manner, the nonexistence of every cause [in the sub-lunar sphere] ('illa nāzila) continues to indicate the nonexistence of the cause [above the moon] ('illa fawqāniyya). Accordingly, [...] the removal of the forms and the accidents necessarily indicates either the removal of the first cause itself or the removal of one of its properties that is taken into consideration as the cause of things that come after its existence. In either case, it follows that the essentially necessary existent is prone to annihilation and nonexistence. And that is impossible. Since this is invalid, the concurrent existence of the effect with its cause does not follow from the existence of the complete cause that accumulates every direction that is taken into consideration in the process of causation (al-illa al-tämma al-mustajmi'a li-jamī' al-jihāt al-mu'tabara fi-al-'illiyya). ${ }^{22}$

Even though al-Rāzī mentions "complete cause" here, while his statement that the concurrence of cause and effect is not necessary appears in a discussion in which he criticizes this same concurrency, it still gives important clues about how he understood "complete cause". At the same time, this enables us to read his usage of this together with that of Avicenna. As a matter of fact, whereas Avicenna talks about the situation (hăl) that completes causation so that the cause can be actualized and the situation's possible conditions with detailed explanations in al-Ishärät, III.V.8, al-Rāzì replaces "state" (h.āl) with "directions" (jihāt) and summarizes the indicated meaning of these explanations as "the accumulation of every direction that is taken into consideration during causation." Al-Rāzì calls this cause, one in which every direction is accumulated, the "complete cause".

Even though his short definition here is connected with Avicenna's passage of al-Ishārāt, III.V.8 on the semantic level, it shows that al-Rāzìs opinion differs from that of Avicenna when it comes to causal necessity and the concurrency of cause and effect, because he does not accept that the cause's existence necessitates the effect's existence. According to Avicenna, who believes that the effect comes into existence necessarily and concurrently with its cause when every causal condition has been fulfilled, the effect's nonexistence leads us to cause's nonexistence, because if the cause exists, then its effect must come into existence with it. On the other hand, in this passage al-Rāzĩ focuses on whether the nonexistence of the sub-lunar effects indicates the nonexistence of above the moon causes, rather than focusing on whether the nonexistence of forms and accidents in our world indicates the nonexistence of their physical causes. He does so because when the perception that "the removal of effect requires the removal of cause" (i.e., the view of the concurrent existence of cause and effect) is taken to the metaphysical level, it has the potential risk of bringing with it the view that nonexistence can be at- 
tributed to God, the ultimate cause of sub-lunar beings, in terms of causation. AlRāzî contends that this problem can be solved only by asserting that even though a complete cause exists to fulfill every condition of causation, the effect's existence does not necessarily follow from it. ${ }^{23}$

Al-Rāzī's short explanation of complete cause here, as well as the context in which it is situated, open the door for a possible interpretation with regard to the function that he places on the complete cause: None of the causes involved in causation can be accepted as superior to God's will, for (1) al-Rāzì raises the complete cause from the physical to the metaphysical level (he uses the concept in a framework and a context $\mathrm{t}^{24}$ that include God) and (2) his usage of "accumulator" (mustajmi'a) in the definition of "complete cause". Al-Rāzī uses "accumulator" to emphasize the necessary coalescence of every direction that participates in causation. This situation raises the question of the identity of this thing that accumulates every direction involved in causation. Given that the participating causes cannot get together by themselves, one might think that al-Rāzì attempts to make God's will the agent of this action. As a matter of fact, in that part of his al-Matālib where he discusses human action in relation to God's creation, he uses majmü', which is derived from the same root as mustajmi' $a$, when stating that the summation of power and $d \bar{a} \bar{l}$ (motive) necessitates the emergence of human action and that the agent of majmü' is God:

It is demonstrated clearly that the summation (majmū $)$ of $d \bar{a} \hat{\imath}$ and power necessitates the emergence of action. If God the Exalted creates power and $d \bar{a} \bar{t}$, then the action becomes necessary; if He does not create the summation of these two (majmü'uhumā), then the action becomes impossible. Then it is established that man, as the servant of God, is not free by himself in the creation of his action. ${ }^{25}$

23 One factor that determines al-Rāzì's approach toward the problem he sees in Avicenna's metaphysics is that al-Rāzi is a theologian (mutakallim). This is because when this perception of the concurrence of cause and effect is carried to the metaphysical level, it follows that God is the complete cause, which necessarily generates its effect. This leads to the conclusion of temporarily connected existence of God and the effect he generates, which would lead to the perception of eternity of the world on one hand, and impair the perception of God as "the free agent" (fä́il mukhtār). Al-Rāzĩ seems to accept neither of these conclusions, both of which follow from the perception of the concurrence of cause and effect. See Eşref Altaş, Fahreddin er-Râzînin İbn Sînâ Yorumu ve Eleştirisi (İstanbul: İz Yayıncılık, 2009), 225-26, 374-81, 463-70.

24 The usage of "complete cause" in a context related directly to God is seen most clearly in the works of Nașîr al-Dīn al-Ṭūsī. Al-Ṭūsī mentions the "complete cause" in the first lines of his short treatise Risāla fĩ al-illa al-tãmma when he discusses the inseparable connection between the necessary existent (i.e., the first cause and essential principle of all things) and its effect. For the edition, translation, and analysis of this treatise, see M. Fatih Kılıç, "Nasîrüddin et-Tûsî̀nin Ezelî İlkelerle Hâdis Varlıkların İrtibatı Hakkındaki Bir Risâlesi (Risâle fi'l-illeti't-tâmme)”, Mukaddime VIII/1 (2017): 137-53. 
Al-Rāzì defines $d \bar{a} \bar{i}$ as conjecture, opinion, or knowledge as to whether the action that is about to be taken is beneficial or detrimental, ${ }^{26}$ and power as the collection of the soundness of the bodily parts, the removal of obstacles, and the ripeness of time and tools. ${ }^{27}$ Thus he attributes the emergence of human actions to God's summation of majmü' and $d \bar{a} \hat{\imath}$. When we consider this example mentioned in the context of human actions ${ }^{28}$ together with the definition of complete cause given above, one can say that the $d \bar{a} \hat{\imath}$ and power created by God correspond to the directions taken into consideration during causation and that God's summation of them corresponds to the complete cause. From this point of view, one can perhaps posit that, at least in al-Rāzī's opinion, a complete cause that has enough sufficiency to generate its effect emerges not just by God's creation of every direction during causation, but also by His will's summation of them. This interpretation is also compatible with Ash'arite kalām, which sees God as the free agent ( $f \bar{a}$ 'il mukhtār) and rejects the necessity of causation in the natural processes. Accordingly, it seems that al-Rāzì uses "complete cause" to show that all of the causes involved in causation cannot generate the effect by themselves and thus attributes a meaning and a function to the concept, which includes God's will in the completion of the process.

Along with al-Baghdādī, al-Rāzì does not mention "incomplete cause" in his texts. However, one can comment on how it would be defined by referring to the short definition he provides for "complete cause". According to this, the incomplete cause represents only some of the directions taken into consideration during causation. Furthermore, the presence of every direction does not mean that they constitute a complete cause, because there has to be a divine will that sums up all of the causes so that the complete cause can exist.

Al-Suhrawardī (d. 587/1191), another contemporary of al-Rāzì, also tries to define "complete cause", which is one side of the complete-incomplete cause distinction. In the metaphysics section of his al-Lamahăt, a book that mostly follows the Avicennian tradition, he writes:

The complete cause is something that is the cause of a thing, and the cause of all its parts, and the cause of its existence, and the cause of its continuance (al-illa al-tämma mā hiya 'illa al-shay' wa 'illa jamī' ajzä'ih wa 'illa wujūdih wa thabātih). The complete cause is not like a carpenter, because the carpenter is the cause of the whole on account of his being solely the cause of the form.

27 Fakhr al-Dīn al-Rāzī, al-Arbaîn fĩ ușūl al-dīn, ed. Aḥmad Hijāzī al-Saqā (Cairo: Maktaba al-Kulliyyāt al-Azhariyya, 1986), I, 175,9-11.

28 For the detailed explanations about the emergence of human actions in al-Rāzīs thought, see Ayman Shihadeh, The Teleological Ethics of Fakhr al-Dīn al-Rāzī (Leiden and Boston: Brill, 2006), 17-44. 
[...] The effect's existence depends on the cause. This is so with regard to the directions (jihāt) that make the cause a cause: the existence of the necessary things (wujūd mā yanbaghì) and the nonexistence of the unnecessary things ('adam mà là yanbaghì) [in the process of causation]. This is just like the need for an assistant (mu'âwin), time (waqt), will (irāda), or a motive ( $d \bar{a} \bar{i})$ that necessities the will, as well as the existence of [the required] conditions in the whole (wujüd sharț), the removal of the obstacle (intifä' mäni), and every element which make themselves the cause a cause. All of these components take part in the causation and generation of the effect. If they exist, then the effect's existence becomes necessary. Otherwise, the cause cannot become a cause [in actuality]. The effect's nonexistence also depends on the cause's nonexistence, whether with the nonexistence of all or just some of its parts. As long as the cause's nonexistence continues according to these two manners, the effect's nonexistence continues. The cause's existence becomes complete and continues to be so, and then the effect follows the cause. ${ }^{29}$

Suhrawardi's explanation here can be considered a reproduction of Avicenna's statements made in his al-Ishārāt, III.V.8. As a matter of fact, he puts the components that complete a cause in order, such as assistant, time (waqt), will (irāda) and motive, so that it can be a complete cause in actuality. He also tries to show the conditions under which the effect becomes necessary. The most important feature that separates this passage from al-Ishārāt, III.V.8, is its inclusion of "complete cause", which exists in Avicenna's passage not as a concept but as a meaning, from the beginning as a frame that contains all of the conditions of causation and, more importantly, provides a definition for it. In this definition, Suhrawardi states that all of the components that generate the effect's existence constitute the complete cause (i.e., no other cause is required), that the effect's existence depends entirely upon the complete cause, and, moreover, that the complete cause also provides the effect's continuance and maintenance.

When the second paragraph is read as an explanation and definition of "complete cause", one can say that this type of cause, which generates its effect with all of its parts and provides its continuance, does not indicate something that belongs to a specific and fixed group of causes (e.g., the efficient or the final cause), but rather indicates something that sums all of the factors of causation that require all of the conditions that are necessary for the effect to exist.

Like al-Baghdādī and al-Rāzī, Suhrawardī does not include "incomplete cause" in his discussions. However, by studying his definition of complete cause, one can comment that he held that the incomplete cause (even though it is a cause) is not the cause of all parts of the effect, its existence, and its continuance. Nevertheless, 
we must wait for Athīr al-Dīn al-Abharī (d. 663/1265) to see when the complete-incomplete cause distinction started to be made clearly and without needing any interpretation in the causation parts of the theological-philosophical texts.

\section{Standardizing the Distinction: al-Abharī}

Al-Abharī includes the complete-incomplete cause distinction in most of his works that contain physical and metaphysical discussions; however, this distinction is not made equally clear in every one of them. When its development is taken into consideration, his works can be divided into three groups: (1) Hidāya al-Hikma, Zubda al-Haqā'iq, and Zubda al-asrār; (2) Tanzīl al-afkār and Kashf al-haqā̄iq; and (3) 'Unwān al-ḥaqq and Talkhīs al-ḥaqā'iq. He talks only about the complete cause in the causation sections of the first group of works. In the causation sections of the second group of works, he divides the causes into complete and incomplete (ghayr tämm). In the causation sections of the third group of works, he clearly mentions the distinction between them.

(1) In the causation section of his Hidāya al-hikma, al-Abharī defines "cause" as "something that has an existence in itself and generates the existence of something other than itself" and states further that it is divided into material, formal, efficient, and final. ${ }^{30}$ Later on in this section, he mentions "complete cause" and provides a short explanation:

$$
\begin{aligned}
& \text { إن المعلول يجب وجوده عند وجود علته التامة أعني عند تحقق جملة الأمور المعتبرة في تحققه. لأنه لو لم }
\end{aligned}
$$

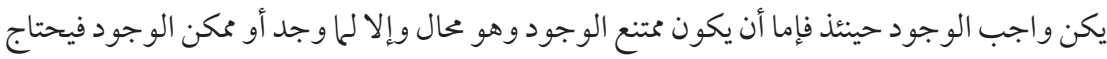

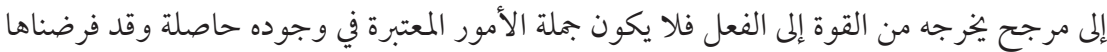

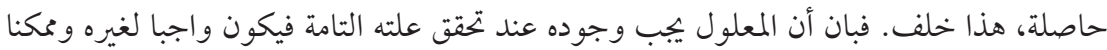

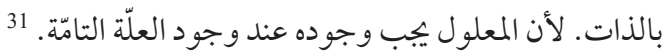

The effect's existence becomes necessary when there is the complete cause for it, that is to say, when every condition that is to be taken into consideration has materialized for it. This is because if the effect does not come into existence when there is a complete cause for it, then either its existence is impossible - that [the effect's existence] is absurd and cannot happen [in this case] - or that the effect is contingent and still needs a preponderator (murajiih) to generate its existence from potentiality into actuality - and

30 Abdullah Yormaz, "Hidâyetü'l-Hikme'nin Tenkitli Neşri”, Marmara Üniversitesi İlâhiyat Fakültesi Dergisi 34 (2008): 207,5-7.

31 Yormaz, “Hidâyetü'l-Hikme'nin Tenkitli Neşri”, 208,4-12. 
in this case, every condition that is to be taken into consideration is not materialized for it. But as we have already assumed that the conditions have materialized, this means that there is a contradiction here. This clearly demonstrates that the effect's existence becomes necessary when there is a complete cause for it, and that the effect is necessary with regard to something else and contingent with regard to its own self.

The short expression here about the nature of complete cause resembles the definition given by al-Rāzī in his al-Mațālib. According to al-Abharī, the complete cause, which al-Rāzī defines as the cause that accumulates every direction taken into consideration during causation, emerges when every condition that is to be considered has materialized. After this, the casual connection between the cause and the effect becomes necessary. In this passage, al-Abharī also tries to justify rationally how the necessity in question comes about in causation. The key concept here, which seems to be given in an Avicennian framework, is the complete cause in which everything to be taken into consideration emerges with regard to the effect's existence. The attribution of "complete" attached to "cause" reveals that he bases the cause's sufficiency upon the effect's generation.

The concept of incomplete cause is absent from al-Abharī's Hidāya al-hikma. Moreover, he makes no distinction between complete and incomplete causes in his explanations regarding the cause's parts, which he provides in the introduction of the causation section of his Zubda al-asrār ${ }^{32}$. There, he mostly cites the above mentioned passage; however, the distinction he makes between the causes that do and do not participate in the effect indicates the Avicennian distinction of internal and external causes. ${ }^{33}$ In other words, al-Abharī does not point to the complete-incomplete causes distinction in the causation section of his Zubda al-haqa'iq, but rather preserves the meaning of complete cause that he gives in Hidāya al-hikma and Zubda al-asrār. ${ }^{34}$ His usage of "complete cause" in these three works contributes nothing significant to the statements of al-Baghdādī, al-Rāzì and Suhrawardī about this concept. It seems that al-Abharī was unaware of the complete- incomplete causes distinction. this section, al-Abharī defines "complete cause" as follows: Everything on which something’s existence depends is called the "complete cause". Zubda al-häquäiq, 154a,21-154b, 1. 
(2) This distinction begins to appear more clearly in his second group of works, where he states, at the beginning of the causation section of his Tanzìl al-afkār:

$$
\begin{aligned}
& \text { في أقشام العلّة }
\end{aligned}
$$

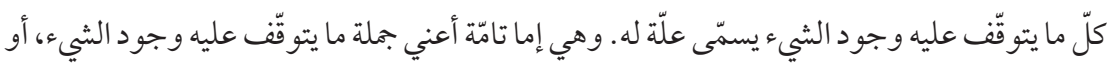

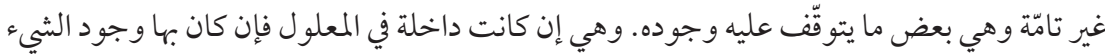

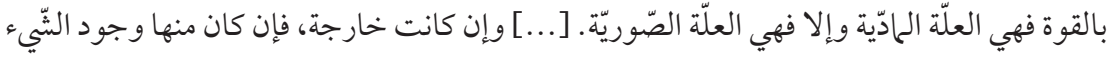

$$
\begin{aligned}
& \text { فهي العلّة الفاعليّة، وإن كانت لأجلها الو جود فهي العلّة الغائيّة. } 35
\end{aligned}
$$

\section{The Classification of Causes}

Everything on which a thing's existence depends is called its "cause". The cause is either complete or incomplete. By complete cause, I mean the summation of things on which something's existence depends. An incomplete cause, however, is some part of the things on which something's existence depends. If the cause is internal to the effect and the thing's existence is in potentiality with the cause, then the cause is called "material". Otherwise, it is called "formal". [...] If the cause is external to the effect and the thing's existence is generated from it, then the cause is called "efficient". If the thing comes into existence for the sake of the cause, then the cause is called "final".

In contrast to his Hidāya al-ḥikma and Zubda al-asrār, in this passage al-Abharī accommodates this distinction at the beginning of the causation section, after giving the definition of "complete cause". This distinction, which he makes before the Avicennian distinction of internal and external causes, also includes a short definition of complete and incomplete causes: The former is defined as something that generates its effect's existence without needing anything other than itself (i.e., it is a sufficient cause upon which the effect's existence is entirely dependent), whereas the latter is something that cannot generate its effect by itself and thus is insufficient with regards to causation. The phrase "the summation of things on which something's existence depends", which appears in the definition of complete cause, gives the impression that this particular cause is a composite (murakkab) group of causes that consists of several, as opposed to just one, causes. Tanzīl al-afkār contains no explanation that takes this impression into consideration and, accordingly, no statement on whether the complete cause is composite or simple. Thus, at the beginning of causation section of his Kashf al-haqā'iq, al-Abharī seems to be giving a short answer to the question that this impression raises in one's mind: 


$$
\begin{aligned}
& \text { العلّة هي الأمر الذي يحتاج إليه الشّيء. فمنها ما هي } 36 \text { التامّة التي يجب بها الشّيء. وقد يكون مركّبة } \\
& \text { من أمور يصدق على كلّ واحد منها أنّه محتاج إليه }{ }^{37} \text { وقد لا يكون كذلك. ومنها ما هي غي تهي تامّة أعني } \\
& \text { بعضا من العلّة التامّة. }
\end{aligned}
$$

The cause is something that the thing needs. The complete, with which something's existence becomes necessary, is one part of it. The complete cause sometimes becomes a composite, of which every constituent needs. And sometimes it becomes simple. There is in the parts of cause a cause that is not complete. I mean by this the cause that is a constituent part of the complete cause.

Al-Abharī, who defines complete cause here as the cause that necessitates its effect, states that while this cause can consist of several constituent parts, it can also correspond to a simple and single cause. According to this approach, the complete cause appears as something composite (murakkab) if it consists of a group of causes in which certain causal factors can participate, as required by the effect. On the other hand, the complete cause may also appear as an independent simple cause if it has enough sufficiency to generate its effect on its own. One can understand from this that this explanation presents an incomplete cause as a cause or a collection of causes that take part in a group of causes, because a simple cause cannot be divided and thus cannot contain any partial causes. Accordingly, an incomplete cause cannot be part of a simple complete cause.

(3) This distinction becomes clearer and conceptually more sophisticated in 'Unwān al-haqq, which falls within the third group of al-Abharī's works in terms of the complete-incomplete causes distinction:

In Sarığlu's edition, the phrase "ما هي" becomes "ماهية". See Athīr al-Dīn al-Abharī, Kashf al-ḥaqāiq fï tahriir al-daqä’iq, ed. Hüseyin Sarıŏ̆lu (İstanbul: Çantay Kitapevi, 1998), 293,10. However, since the distinction of complete and incomplete (näqiș) is made here with regard to cause and not with regard to essence, Sarığlu's preference seems to be incorrect.

37 Najm al-Dīn al-Kātibī (d. 675/1277), who copied al-Abharī’s Bayān al-asrār, Talkhīs al-haqā’iq, al-Matāli , and Zubda al-haqẩiq, uses a similar statement in his correspondence with al-Ṭūsì regarding the proof of the necessary existent as such:

" Nașīr al-Dīn al-Ṭūsī, Ajwiba al-masä’il al-Nașriyya, ed. 'Abdullāh Nūrānī (Tehran: Pajuhashgāh-i ‘Ulūm-i Insānī ve Mutāla'āt-i Farhangī, 1383), 115,4-5.

38 Athīr al-Dīn al-Abharī, Kashf al-ḥaqã’iq, Kutubkhāne-i Majlis-i Shūrā-i Millī 3297, 129,23-130,2. 


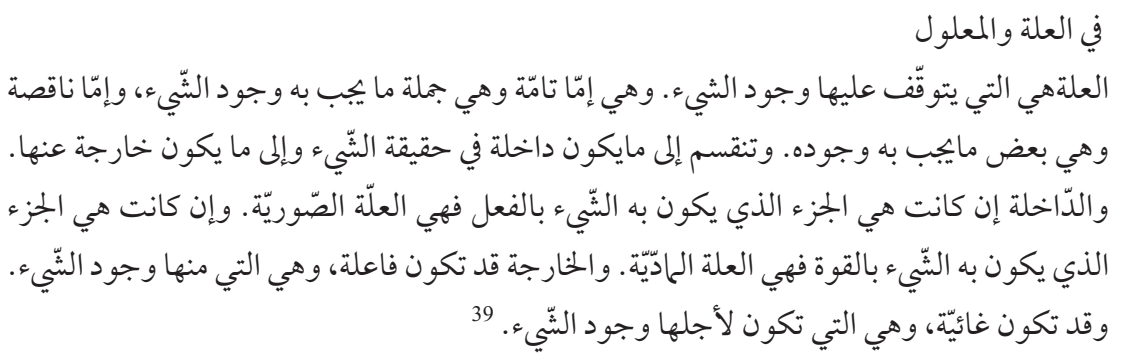

\section{On the Cause and the Effect}

The cause is something on which a thing's existence depends. It is either complete or incomplete. The complete cause is the summation of things with which the existence of something becomes necessary. The incomplete cause is some part of the things with which the existence of something becomes necessary. The cause is divided [into two], as one is internal in the thing's essence and one is external to the thing's essence. If the cause that is internal in the effect is a part that actualizes the thing's existence, then it is called "formal"; if it is a part that makes the thing's existence potential, then it is called "material". The cause that is external to the thing's essence sometimes becomes an efficient cause from which the thing's existence is generated and sometimes becomes a final cause for the sake of which the thing comes into existence.

Right after defining "cause" in association with the causes, al-Abhari makes a distinction between complete and incomplete causes. Even though he shows some regression in this work by not mentioning their composite or noncomposite structure in his explanations on the nature of a complete cause in comparison with his explanations provided in Kashf al-haqā'iq, he does bring the complete-incomplete causes distinction in his works to a certain level of standardization. Besides, in this passage al-Abharī mentions the Avicennian distinction between internal and external causes along with the complete-incomplete causes distinction that is connected with casual sufficiency. Moreover, his use of "the thing's essence" points to the Avicennian distinction between essential and existential causes more strongly than he does in his other works.

In his Talkhīṣ al-ḥaqā’iq, al-Abharì defines complete and incomplete causes separately. The first part of al-'Ilm al-Ilāhī, this book's third section, is devoted to the necessary and contingent existent. He provides the following two definitions: 


$$
\text { و والعلَة التامَة للشَيء هي التي يجبَ بوجودها وجود الشَّيء، ويمتنع بعدمها وجوده. }
$$

The thing's complete cause necessitates that thing's existence with its existence and makes that thing's existence impossible with its nonexistence.

A thing's incomplete cause makes that thing's existence impossible with its nonexistence; however, it does not necessitate that thing's existence with its existence.

What separates these definitions most remarkably from other definitions, not in respect to their meanings but in respect to their constructions, is the language that the section on necessary and contingent existence, in which this passage is located, requires. As a matter of fact, the passage states that the complete cause necessitates the existence of its effect by itself and, on the other hand, that even though the incomplete cause is required for the effect's existence, it is not sufficient by itself for the effect's existence. Al-Abharī provides no detailed explanations about the content of complete and incomplete causes, even in the passage in which he gives these definitions. He continues his discussion by providing some explanations about internal and external causes, just as he does in the causation sections of the second and third groups of his other works.

One can see in the classification made about the causes that, besides the distinctions made between internal and external causes and of essential and existential causes, the complete-incomplete distinction becomes more standardized with al-Abhari. This classification can be seen at the beginning of the section on the parts of causes in Hikma al-'ayn, authored by his student al-Kātibīi, ${ }^{41}$ who died a short time after him. Al-Kātibī, who defines "complete cause" as "all the things on which something's existence depends" (jamī' mā yatawaqqaf 'alayh wujūd al-shay'), defines "incomplete cause" as "some of the things on which something's existence depends" (ba'd mā yatawaqqaf'alayh wujūduh). ${ }^{42}$ In the same century, Shams al-Din al-Shahrazūrī (d. 687/1288) mentions the complete-incomplete causes distinction in the causation section of his al-Shajara al-Ilähiyya. While he defines the former as "the thing that from its existence generates another thing' (yahșul min wujūdihā wujūd shay' äkhar), he defines the latter as "the thing that takes part in something's

40 Athīr al-Dīn al-Abharī, Talkhīs al-ḥaqã’iq, Murad Molla Kütüphanesi, No: 1406, v. 89a,9-11.

41 Mustakim Arıcı, Fahreddin Râzî Sonrası Metafizik Düşünce Kâtibî Örneği (İstanbul: Klasik Yayınları, 2015), 40-41.

42 Najm al-Dīn al-Kātibī, Hikma al-'ayn wa-al-Sharḥ li-Shams al-Dīn Mubārakshāh (Mashhad: Dānishgāh-i Firdawsī, 1974), 174,13-175,7. 
existence" (lahā madkhal fï wujūd al-shay') and "that its nonexistence makes the effect's existence impossible" (yamtani' al-shay' bi-'adamihā), but that "its existence only does not necessitate the existence of effect (lā yajib bi-wujūdihā wahdahāa)" ${ }^{43}$

The presence of this distinction in philosophical-theological works from the thirteenth century onward indicates the existence of a standard version of the distinction itself, but not a standardization of the explanations given about their definitions. As a matter of fact, the definitions in these works were amended slightly over the following centuries, and the philosophers and theologians' disputes and various explanations can be traced via the commentaries (sharhs) and annotations (hashiyas) made on al-Kātibī’s Hiikma al-'ayn, al-Ṭūsī’s Tajrīd, 'Aḍud al-Dīn al-İjī's (d. 756/1355) Mawāqif, and al-Taftāzānī’s (d. 792/1390) Maqāṣid.

The discussions about the definitions of complete and incomplete causes also occupy an important place in Ottoman thought. Ibn Kamāl (d. 940/1534) presents detailed analyses in his Risāla fì Taqaddum al-'Illa al-Tāmma 'alā al-Ma'lūl by relying primarily upon this tradition of commentaries. ${ }^{44}$ Tashkoprīzāda Aḥmad Afandī's (d. 968/1561) later al-Nahal wa-al-'alal fì tahqìq aqsām al-ílal also contributed to this discussion by incorporating Ibn Kamāl's analyses. ${ }^{45}$

\section{Conclusion}

Avicenna's statement in his al-Ishārāt, III.V.8, namely "the completion of the cause as an actual cause" (tatmìm kawn al-illa 'illa bi-al-fi'l) and the explanations he provided there clearly served as a background for the complete-incomplete causes distinction, especially its "complete" part, that emerged two centuries after his death and acquired a standard version with al-Abhari. However, it seems hard to say that "complete", "incomplete", or similar words derived from them, used by Avicenna, along with "cause" played any effective role in the complete-incomplete causes distinction because Avicenna's use of these two concepts arose in the context of their perfection as opposed to the context of their sufficiency.

43 Shams al-Dīn al-Shahrazūrī, Rasā’il al-shajara al-ilāhiyya, ed. M. Necip Görgün (İstanbul: Elif Yayınları, 2004), 135,23-136,7.

44 For this work, see Ahmet Cesur, "Kemâlpaşazâde'nin Risale fì Tekaddümi'l-'illeti't-tâmme 'Ale'l-Ma'lûl Adlı Eserinin Tahkik, Tercüme ve Değerlendirmesi” (Master's Thesis, Sakarya Üniversitesi Sosyal Bilimler Enstitüsü, 2011), 77-116.

45 For this work, see Tashkoprīzāda Aḥmad Afandī, al-Nahal wa-al-'alal fì tahquĩq aqsām al-ílal, Majmū' alrasā'il al-falsafiyya, Ex Biblioth. Regia Berolinenli, Sprenger, no: 1823, 56b-83b. 
On the other hand, one can think that the Avicennian distinction between essential and existential causes impacted this distinction. As a matter of fact, this distinction emphasized that the material and formal causes only are insufficient for something's existence and, along with them, that there have to be an efficient cause and a final cause that give the thing existence by influencing it from the outside. When read from the perspective of the complete-incomplete causes distinction, one can comment that those causes making up a thing's essence are incomplete because they cannot generate the thing's existence by themselves, and that the causes that make up the thing's essence and existence are complete because they necessitate, when taken together, the thing's actual existence. In addition, one interpret the complete-incomplete causes distinction as having influenced the distinction of reason (sabab) and cause ('illa), as seen in the example provided by Qādī 'Abd al-Jabbār. Accordingly, one can say that the insufficient cause, which still has an influence on the effect's generation, is incomplete, whereas the cause that necessitates the effect is complete.

The explanation that al-Rāzī gives in his al-Mațālib, as well as the context in which it occurs, gives some clues for possible interpretations with regard to the reason behind the need for the complete-incomplete causes distinction together with other classifications of causes that influenced its construction. These interpretations can be made around God and His will, which transcends the content of "accumulator" (mustajmi'a) used by al-Rāzì in connection with the complete cause in this passage. From this statement, one can say that the Ash'arite theologians's utilization of this distinction means both the acceptance of causes in an Avicennian framework and the presentation of dissension against causal necessity, because given that the complete cause can become complete only with God's will (which fulfills the requirement of accumulating all of the causes), the actualization of the effect's existence during causation cannot be understood independently from God's will. This interpretation can explain why this distinction was found in theological circles after al-Rāzī, for it is compatible with Ash'arite theology, which sees God as a free agent ( $f a \bar{i} i l$ mukhtār) and rejects causal necessity. When al-Rāzī's usage of "complete cause" in his al-Mațālib and his explanations about human actions are considered together, one can posit that this distinction was devised to endorse the identification of human actions with God.

One can say that al-Abharī, who pretty much standardized this distinction, is concerned primarily with the terms' conceptualization rather than their physical and metaphysical functions. However, his conceptualization, developed with the help of his predecessors, contributed significantly to later conceptual thinking by presenting a framework for those philosophical-theological works that dealt with ontology. 
In addition to the possible interpretations of this distinction and particularly of al-Rāzī, within the limits of this article one can provide a sufficient answer as to whether the complete-incomplete causes distinction arose from a more advanced paradigmatic need and brought with it more developed thought only after conducting a careful investigation of the philosophical-theological texts written after the thirteenth century. Further investigations about the contexts in which the concepts of these two causes are used and about the discussions of their definitions are needed to shed light on the paradigmatic needs that generated this particular distinction and on its later development.

\section{Bibliography}

Al-Abharī, Athīr al-Dīn. Kashf al-ḥaqā’iq fì tahrīr al-daqāiqq. Ed. Hüseyin Sarıŏlu, İstanbul: Çantay Kitabevi, 1998.

—. Kashfal-ḥaqā’iq, Kutubhāne-i Majlis-i Shūrā-i Millī 3297.

—. Talkhīs al-ḥaqā’iq, Murad Molla Halk Kütüphanesi 1406, 58b-98a.

—. Tanzīl al-afkār. Süleymaniye Kütüphânesi, Reisülküttâb Mustafa Efendi 569, 1b-123a.

'Unwān al-ḥaqq wa burhān al-ṣidq. İstanbul Üniversitesi Nadir Eserler Kütüphanesi, Hâlis Efendi Collection 3134, 1b-52a.

—_ Zubda al-asrār. Konya Bölge Yazma Eserler Kütüphanesi, Karaman Collection 925, 1b-125a.

Zubda al-haqā’iq, Murad Molla Halk Kütüphanesi 1406, 136b-182b.

Altaş, Eşref. Fahreddin er-Râzînin İbn Sînâ Yorumu ve Eleştirisi. İstanbul: İz Yayıncılık, 2009.

"Fahreddin er-Râzînin Eserlerinin Kronolojisi”. İslam Düşüncesinin Dönüşüm Çağında Fahreddin erRâzî, ed. Ömer Türker and Osman Demir, 91-164. İstanbul: İSAM Yayınları, 2013.

Arıcı, Mustakim. Fahreddin Râzî Sonrası Metafizik Düşünce: Kâtibî Örneği. İstanbul: Klasik Yayınları, 2015.

Al-Baghdādī, Abū al-Barakāt. Kitāb al-Mu'tabar I-III. Hyderabad: Dā'ira al-Ma'ārif al-Uthmāniyya, 1357.

Cengiz, Yunus. Mu'tezilede Eylem Teorisi Kâdî Abdülcebbâr Örneği. İstanbul: Düşün Yayıncılık, 2012.

Cesur, Ahmet. “Kemâlpaşazâde'nin Risâle fî Tekaddümi'l-'illeti’t-tâmme 'Ale'l-Ma'lûl Adlı Eserinin Tahkik, Tercüme ve Değerlendirmesi”. Master's Thesis, Sakarya Üniversitesi Sosyal Bilimler Enstitüsü, 2011.

Demir, Osman. Kelâmda Nedensellik: İlk Dönem Kelâmcılarında Tabiat ve İnsan. İstanbul: Klasik Yayınları, 2015.

Ibn Sīnā. al-Ishārāt wa-al-tanbīhāt I-IV. Ed. Sulaymān Dunyā. Cairo: Dār al-Ma‘ārif, 1960.

Kitāb al-Hidāya. Ed. Muhammad 'Abduh. Cairo: Kulliyyāt Dār al-'Ulūm, 1974.

- Kitāb al-Shifã', al-Ilāhiyyāt I-II. Ed. Ibrahīm Madkūr, al-Ab Qanawātī and Sa īd Zāyid. Cairo: al-Hay’a al-'Āmma li-Shu'ūn al-Mațābi' al-Amīriyya, 1960.

Remarks and Admonitions: Physics and Metaphysics. Trans. Shams C. Inati. New York: Columbia University Press, 2014.

al-Ta‘liquāt. Ed. Ḥusayn Majīd ‘Ubeyd. Baghdād: Bayt al-Ḥikma, 2002. 
Al-Kātibī, Najm al-Dīn. Hikma al-'ayn wa-al-Sharḥ li Shams al-Dīn Mubārakshāh. Mashhad: Dānishgāh-i Firdawsī, 1974.

Kılıç, M. Fatih. "Nasîrüddin et-Tûsînin Ezelî İlkelerle Hâdis Varlıkların İrtibatı Hakkındaki Bir Risâlesi (Risâle fi'l-'illeti't-tâmme)”. Mukaddime VIII/1(2017): 137-53.

McGinnis, Jon. Avicenna. Oxford, New York: Oxford University Press, 2010.

Qādī 'Abd al-Jabbār. al-Mughnī fí abwāb al-tawhīd wa-al-'adl. Ed. Muhammad Musțafā Hilmī and Abū al-Wafā al-Ghunaymī. Cairo: al-Dār al-Mișriyya, 1963.

Al-Rāzī, Fakhr al-Dīn. Al-Arbaìnn fì uṣūl al-dīn I-II. Ed. Aḥmad Hijāzī al-Saqā. Cairo: Maktaba al-Kulliyāt al-Azhariyya, 1986.

- al-Mabāhith al-Mashriqiya fỉ 'ilm al-ilāhiyyāt wa-al-țabīinyyāt I-II. Qum: Intishārāt-i Bīdār, 1370.

. al-Mațālib al-'Āliyya min al-'ilm al-ilāhī I-IX. Ed. Aḥmad Ḥijāzī al-Saqā. Beirut: Dār al-Kitāb al-'Arabī, 1987.

. Sharḥ al-Ishārāt wa-al-tanbīhāt I-II. Ed. 'Ali Riḍā Najafzāda. Tehran: Anjuman-i Āthār-i wa Mafākhir-i Farhangī, 1384.

Ruffus, Anthony and McGinnis, Jon. "Wilful Understanding: Avicenna's Philosophy of Action and Theory of the Will”. Archiv für Geschichte der Philosophie 97/2 (2015): 160-195.

Al-Shahrazūrī, Shams al-Dīn. Rasā’il al-shajara al-ilāhiyya. Ed. M. Necip Görgün. İstanbul: Elif Yayınları, 2004.

Shihadeh, Ayman. The Teleological Ethics of Fakhr al-Dīn al-Rāzì. Leiden and Boston: Brill, 2006.

Al-Suhrawardī, Shihāb al-Dīn. Kitāb al-Lamaḥāt. Ed. Emile Maalouf. Beirut: Dār al-Nahār, 1969.

Tashkoprīzāda Ahmad Afandī. al-Nahal wa-al-'alal fì tahquĩq aqsām al-ílal, Majmū'al-rasāỉl al-falsafiyya, ExBiblioth. Regia Berolinenli, Sprenger, No: 1823, 56b-83b.

Al-Ṭūsī, Nașīr al-Dīn. Sharḥ al-Ishārāt wa-al-tanbīhāt I-IV. Ed. Sulaymān Dunyā. Cairo: Dār al-Ma'ārif, 1960.

Ajwiba al-masā̉il al-Nașriyya. Ed. 'Abdullāh Nūrānī. Tehran: Pajuhashgāh-i 'Ulūm-i Insānī wa Mutāla'āt-i Farhangī, 1383.

Wisnovsky, Robert. “Avicenna on Final Causality”. Phd Dissertation, Princeton University, 1994.

“Towards a History of Avicenna's Distinction Between Immanent and Transcendent Causes”. Before and After Avicenna: Proceedings of the First Conference of the Avicenna Study Group, ed. David C. Reisman, 49-68. Leiden and Boston: Brill, 2003.

Yormaz, Abdullah. “Hidâyetü'l-Hikme'nin Tenkitli Neşri”. Marmara Üniversitesi İlâhiyat Fakültesi Dergisi 34 (2008): 145-228. 